\title{
NDD2020 gaat door: een veelbelovende vooruitblik
}

\begin{abstract}
Nationale Diabetes Dag 2020 zou oorspronkelijk plaatsvinden in april maar werd vanwege COVID-19 verplaatst. Het congres zal nu plaatsvinden op 16 oktober. In aangepaste vorm, zie nationalediabetesdag.nl. NTD heeft het veelzijdige congresprogramma voor $u$ verkend en enkele sprekers uitgenodigd om een tipje van de sluier op te lichten. Bij dezen: een veelbelovende vooruitblik in tien abstracts.
\end{abstract}

\section{DE DIABETESSAMENLEVING \\ Maria van den Muijsenbergh, Radboudumc}

Hoe komt het dat zo veel mensen diabetes type 2 hebben? En dat mensen met weinig opleiding of inkomen, of met een migratieachtergrond zo veel vaker diabetes krijgen dan de gemiddelde Nederlander? Komt dat alleen door te veel eten en te weinig bewegen? Nee! Er is meer aan de hand in onze samenleving waardoor de kans op diabetes vergroot wordt. Chronische stress blijkt daarbij een belangriike rol te spelen. We leven in een gejaagde maatschappij, met ontzettend veel prikkels en informatie. Een samenleving die veel eist van mensen, van hun vaardigheden om met alles mee te doen, om ingewikkelde informatie te snappen en procedures online zelfstandig uit te kunnen voeren. Een samenleving waar heel veel mogelijk is als je geld hebt, een goede opleiding, een goede gezondheid, 'erbij hoort'. Maar waarin het leven veel moeilijker is als je weinig geld hebt, lezen lastig vindt, de taal niet kent, eenzaam bent of uitgesloten omdat je er anders uitziet. Ongunstige leefomstandigheden geven veel stress, elke dag weer. En chronische stress werkt op twee manieren diabetes in de hand. Chronische stress leidt tot overproductie van bepaalde hormonen die een nadelig effect hebben op de bloedvaten, het immuunsysteem en de suikerstofwisseling, waardoor eerder hart- en vaatziekten en suikerziekte ontstaan. Behalve een direct nadelig effect op de gezondheid, vermindert chronische stress ook het denkvermogen, en met name het vermogen om langetermijndoelen te stellen. Daardoor is het lastig gemotiveerd te zijn voor deelname aan leefstijlbevorderende activiteiten. Roken en eten en op de bank hangen zijn vaak op korte termijn aantrekkelijker opties dan stoppen met roken, gezond eten en sporten. In het algemeen maakt stress het moeilijker om goede beslissingen te nemen. Als mensen gestrest zijn vertonen ze meer gewoontegedrag en denken ze minder goed na over verschillende opties. Stress leidt dus tot slechte gezondheid en een focus op kortetermijnuitkomsten.

Daar komt nog bij dat voor ongeveer een derde van alle mensen in Nederland informatie over hun gezondheid moeilijk te vinden, te begrijpen of toe te passen is - $\mathrm{zij}$ hebben beperkte gezondheidsvaardigheden. Adviezen over dieet, maar ook medicatievoorschriften, zijn voor hen moeilijker goed toe te passen. Zij hebben dus én een grotere kans op suikerziekte én minder mogelijkheden om goed met die ziekte om te gaan, zodat de kans op complicaties groter is dan wanneer hoogopgeleide, gezondheidsvaardige mensen diabetes type 2 krijgen.

Wat kunnen we als maatschappij, als zorgverleners en als patiëntenverenigingen hieraan doen?

Begrijpelijke taal spreken en informatie voor iedereen toegankelijk maken is één belangrijk ding. Onthaasten zou ook helpen, zodat mensen bij dokters en andere instanties wat meer tijd zouden krijgen en rust zouden voelen. Oog hebben voor elkaar, voor wat elke persoon nodig heeft, zorg op maat is het allerbelangrijkste. Zulke persoonsgerichte zorg en preventie kunnen écht helpen om de kans op diabetes te verkleinen en om het suikerniveau bij diabetespatiënten te verbeteren. Hoe kunnen we met elkaar stappen maken om persoonsgerichte zorg en preventie voor íedereen bereikbaar te maken? Daarover gaat mijn lezing tijdens de Nationale Diabetes Dag.

\section{DE NIEUWE NHG-STANDAARD CVRM: HOE PAK JE DAT AAN IN DE DAGELIJKSE PRAKTIJK? \\ Janneke Spitsbaard-Velmans, huisarts, Utrecht \\ Bertien Hart, huisarts, Utrecht}

Deze sessie is een open DiHAG expertmeeting. De NHGRichtlijn Cardiovasculair Risicomanagement is herzien. Deze multidisciplinaire richtlijn is op een aantal belangrijke punten gewijzigd. Daarnaast is maatwerk van groot belang bij het toepassen van deze richtlijn. Hoe implementeer je deze richtlijn in de dagelijkse praktijk? Hoe schat je risico's in van een diabetespatiënt en hoe leg je dit uit in de spreekkamer? Hoe informeer je en begeleid je een patiënt bij keuzes voor een behandeling? Hoe stellen we de diagnose hypertensie? Wanneer doen we aanvullende diagnostiek? Wat doet leefstijl en wanneer starten we wel of geen medicamenteuze therapie? Is er in de nabije toekomst een plek voor de nieuwe diabetesmiddelen in de huisartsenpraktijk? Op al deze vragen gaan we dieper in tijdens deze sessie. Deze sessie is multidisciplinair, dat wil zeggen dat alle zorgverleners aanwezig op de NDD van harte welkom zijn! Kaderhuisartsen Diana Rietdijk, Bertien Hart en Janneke Spitsbaard-Velmans zullen samen met internisten (vasculair-geneeskundigen) Jan Westerink en Wilko Spiering, deze sessie praktisch insteken en interactief met de zaal dieper op deze onderwerpen ingaan. 
De onderwerpen die aan bod komen zijn:

1. Kwalitatieve risicoschatting bij de patiënt met diabetes in de spreekkamer.

Spreker: Dr. J. (Jan) Westerink, internist vasculair geneeskundige

- Hoe schat ik het risico bij mijn diabetespatiënt in?

- Casus: Inschatten risico bij iemand waarvan je aanvoelt dat hij een hoog risico heeft, en je wilt dat illustreren om te motiveren tot medicamenteuze behandeling (ADVANCE)

- Casus: Jong met diabetes, gunstig risicoprofiel, geen complicaties, schatten life-time risico (DIAL)

- Hoe voer je deze bovenstaande gesprekken in de spreekkamer met de patiënt?

2. Behandeling van hypertensie, aan de hand van een casus (aangeleverd en gepresenteerd door Janneke en Diana)

Spreker: Dr. W. (Wilko) Spiering, internist vasculairgeneeskundige

- Bloeddrukmeting: spreekkamer, geprotocolleerde thuismeting, 24 uursmeting ambulant

- Hoe interpreteren we een lage diastolische bloeddruk en hoe gaan we hiermee om als de systolische wel erg hoog is?

- Wat kun je bereiken met leefstijl? (leuk voor de POH en diëtiste):

- Wat kun je bereiken met afvallen? Wat met bewegen? Wat met voeding? Wat met zoutbeperking?

- Keuzes van antihypertensiva o.b.v. patiënt kenmerken (bètablokker + diureticum en diabetes?)

- Wanneer starten met combinatietherapie?

- Opstarten medicatie en instellen volgens stappenplan en labcontroles?

- Welke bijwerkingen zijn veel voorkomend en hoe ga je hiermee om?

- Wanneer staken van antihypertensiva bij de ouderen?

- CVRM bij jonge diabetespatiënt; wanneer wel/niet bloeddruk behandelen?

3. Zorg op maat; SGLT2-remmers en GLP1 voor iedereen meerwaarde?

Bertien Hart en collegae kaderartsen diabetes Jaap Kroon en Marc Huls.

\section{3. 'CLOSING THE LOOP'}

Roel Nahuis, met medewerking van de in het abstract genoemde personen, Diabetes Fonds

'Closing the Loop' staat voor het automatisch toedienen van insuline. Drie componenten worden onderling verbonden: een glucosesensor, een insulinepomp en een besturingsapp. Zo ontstaat een systeem dat de alvleesklier nabootst door continu glucosewaarden te monitoren en deze waarden realtime te gebruiken om te bepalen of het systeem meer of minder insuline moet afgeven.

Een groep doe-het-zelvers, veelal zelf met diabetes, werkt al geruime tijd aan de ontwikkeling van deze technologie. Onder het motto \#WeAreNotWaiting geven zij aan niet te willen wachten tot de industrie en autoriteiten met oplossingen komen. Ontwikkelaars publiceren in een 'open source'-omgeving algoritmes voor de besturingsapp en instructies voor het zelf bouwen van een systeem. Gebruikers helpen elkaar door het delen van de instructies en documenten en het uitwisselen van ervaringen via Facebookgroepen. Wereldwijd hebben duizenden mensen zo hun eigen kunstalvleesklier gebouwd. In Nederland zijn naar schatting enkele honderden gebruikers. Deze groep groeit naarmate er meer bewijs komt dat suggereert dat betere glucosewaarden haalbaar zijn.

Desondanks lijken zorgverleners huiverig te zijn om dit gebruik te faciliteren. Er is veel onduidelijkheid over de potentiële voordelen en risico's en over welke ondersteuning men kan verwachten van zorgverleners. Ten eerste is er onduidelijkheid of de doe-het-zelfsystemen voldoende veilig en effectief zijn. Veiligheid en prestaties zijn niet in gecontroleerde omstandigheden aangetoond, maar blijken vooral uit real-life gebruik. Ten tweede is het onduidelijk of de doe-het-zelf systemen voldoen aan de geldende regels voor medische hulpmiddelen. Wie is bijvoorbeeld verantwoordelijk voor schade als gevolg van 'off-label' gebruik van de insulinepomp? En ten derde is het onduidelijk welke rol zorgverleners moeten aannemen. Een looper is een patiënt die zelf een behandeling heeft uitgestippeld, met een systeem waarvan niet alle risico's in kaart zijn gebracht. Wat betekent dat voor de relatie tussen behandelaar en patiënt?

Die onduidelijkheid is onwenselijk. Enerzijds blijven bestaande mogelijkheden voor diabetesmanagement mogelijk onderbenut. Anderzijds zijn mensen die de systemen wel gebruiken zich misschien onvoldoende bewust van de risico's van hun handelen. Het onderwerp leidt hierdoor mogelijk tot ongemakkelijke gesprekken in de spreekkamer. Om over deze aspecten meer duidelijkheid te krijgen en het onderwerp bespreekbaar te maken, organiseert het Diabetes Fonds op de Nationale Diabetes Dag 2020 de TOP-sessie 'Closing the Loop' voor zorgprofessionals. In deze TOP-sessie gaan we op zoek naar de knelpunten en behoeften bij zorgverleners. De vraag die hierbij centraal staat is: Als jouw patiënt vraagt of je wilt helpen bij het doehet-zelf loopen, wat antwoord je dan? Tijdens de sessie wordt deze vraag vanuit verschillende perspectieven belicht: dat van de gebruiker, de zorgverlener, de regelgever en de zorgpraktijk in bredere zin.

Joost Hart heeft 20 jaar type 1-diabetes, is ICT'er en loopt sinds 2018. Hij legt uit wat loopen inhoudt en wat loopers beweegt om hun eigen systeem te bouwen. De impact van loopen op zijn gezondheid en kwaliteit van leven is vaak onderwerp van gesprek tussen hem en zijn behandelaar. Die behandelaar is Bas Schouwenberg, internist/klinisch farmacoloog in het Radboudumc. Samen nemen ze het publiek mee in de gesprekken die ze voeren. Ze vertellen hoe Joost zelf een werkend systeem bouwde en Bas hem uitnodigde om hierover te komen vertellen tijdens het wekelijkse overleg van de diabetesgroep in het Radboudumc. Vanaf het begin liggen de kennis en verantwoordelijkheid bij de gebruiker. Zijn behandelaar heeft ervoor gekozen om het te willen begrijpen, mee te denken en waar mogelijk te steunen. Die ondersteuning bestond uit het regelen van een geschikte sensor of pomp, maar ook uit meedenken 
over instellingen en opties. Omdat richtlijnen hier niets over zeggen, gaat Bas Schouwenberg uit van hoe diabeteszorg er volgens hem uit zou kunnen zien: de patiënt behandelt zichzelf nadat de professionals hem de basics hebben bijgebracht om dat te doen. Vervolgens is het behandelteam als een coach vanaf de zijlijn. Spreekkamer gesprekken gaan dan niet meer over sensor- of pompuitdraaien en al helemaal niet meer over het Hbalc-waarden, want die zijn gewoon goed.

Het perspectief van de regelgeving wordt toegelicht door Annette van Raamsdonk, manager Regulatory Affairs bij Emergo. Zij legt uit welke regels gelden voor markttoelating van nieuwe medisch hulpmiddelen. Een belangrijk aspect van het verkrijgen van markttoegang is dat de klinische voordelen van het gebruik van een medisch hulpmiddel zijn aangetoond en opwegen tegen de risico's. Zelfgebouwde systemen worden niet aan die regels getoetst. Daardoor zijn mogelijk niet alle risico's van het gebruik van deze systemen in kaart gebracht. Een ander aspect is dat gedurende de levenscyclus van het medisch hulpmiddel het gebruik gemonitord blijft worden, zodat kan worden ingegrepen als zich problemen voordoen. De fabrikant, maar ook fabrikanten van soortgelijke medische hulpmiddelen, moeten deze data dan in ogenschouw nemen. Waar een gebrek aan informatie is, zal de fabrikant een gecontroleerde klinische studie moeten opzetten, om aan te tonen dat de voordelen van het gebruik van het hulpmiddel opwegen tegen de risico's. Volgens Annette van Raamsdonk zetten loopers, die zelf een systeem bouwen en gebruiken, als het ware hun eigen (ongecontroleerde) studie op. De behandelaar heeft geen inzicht in wat er heeft plaatsgevonden, waardoor ingrijpen bij nood een bijna onmogelijke taak wordt. Strenge wet- en regelgeving komt de innovatie wellicht niet altijd direct ten goede, maar beoogt de patiënt wel te beschermen. Die bescherming heeft de doe-het-zelver volgens Annette niet.

Doe-het-zelvers hebben hun eigen creativiteit aangewend omdat ze niet wilden wachten op industrie en autoriteiten. Henk-Jan Aanstoot, kinderarts-diabetoloog en onderzoeker, gaat in op de impact die deze beweging heeft op de industrie en zorgpraktijk. Loopen is een van de vele nieuwe technieken die de diabeteszorg fors gaat veranderen. Wat heb je immers nog nodig aan glucoseadvies als je systeem het kan regelen? Volgens Henk-Jan wordt Loopen onvermijdelijk onderdeel van diabeteszorg. De vraag is niet óf, maar hoe snel deze ontwikkelingen gaan naar een technische 'genezing' van type 1-diabetes met normale glucosewaardes in vrijwel alle omstandigheden. Er bestaan nu twee methoden: de 'samengestelde oplossingen' van de Loopers en inmiddels ook een aantal 'kant-en-klare' van de industrie. Het is een open vraag welke methode werkt voor wie. Daarbij speelt ook de vraag wat de 'bijwerkingen' zijn van de verschillende systemen, bijvoorbeeld in termen van klinische voordelen, risico's en gebruiksgemak.

Door de afwisseling van perspectieven zal de sessie ongetwijfeld veel reacties oproepen. Hij is daarom interactief opgezet. Onder leiding van Hans de Vries, hoogleraar interne geneeskunde AMC, wordt het publiek uitgedaagd om eigen ervaringen te delen of zelf stelling te nemen.

\section{4. 'VASTE VOET AAN DE GROND'}

Michel Boerrigter, (diabetes)podotherapeut \& secretaris/ bestuurslid Nederlandse Vereniging van Podotherapeuten Igna Breedeveld, medisch pedicure \& secretaris/bestuurslid ProVoet, Lian Stoeldraaijers, (diabetes)podotherapeut \& voorzitter Nederlandse Vereniging van Diabetespodotherapeuten

Tijdens deze sessie zullen we dieper ingaan op de huidige stand van zaken binnen de preventieve diabetische voetzorg en worden praktisch toepasbare handvaten aangereikt aan de hand van casuïstiek. Dit artikel sluit aan bij deze TOP-sessie en zal dieper ingaan op hoe de voetzorg, en de bekostiging daarvan, anno 2020 in Nederland georganiseerd is. We doen dit bewust vanuit een beleidsmatig perspectief om de doorgevoerde veranderingen van de afgelopen jaren inzichtelijk te maken en nemen daarbij ook een vooruitblik op de toekomst.

Het afgelopen decennium heeft de preventieve diabetische voetzorg een enorme ontwikkeling doorgemaakt. De aanleiding hiertoe is een rapport van het College voor Zorgverzekeringen (tegenwoordig het Zorginstituut Nederland) uit januari 2010 geweest (CvZ, 2010). Tot dat moment werd de voetzorg bekostigd uit de aanvullende verzekering. Niet het risico op voetproblemen was leidend voor eventuele bekostiging, maar of de patiënt, de financiële ruimte had om een aanvullende verzekering af te sluiten. In de praktijk leidde dit tot schrijnende situaties in die periode waarbij de ene Sims 3-patiënt wel vergoeding ontving voor de (diabetes)podotherapeut en medisch pedicure, terwijl de andere patiënt dit zelf moest zien te bekostigen. Voor veel mensen met diabetes mellitus was dit simpelweg niet mogelijk met alle negatieve gevolgen van dien. Zoals gezegd is hier veel verandering in gekomen na het verschijnen van het rapport door het College voor Zorgverzekeringen in 2010. Vanaf dat moment is de preventieve diabetische voetzorg stapsgewijs overgeheveld naar de basisverzekerde zorg en daarmee toegankelijk geworden voor alle mensen met diabetes mellitus met een matig tot hoog risico (Sims 2 en 3) op het ontwikkelen van voetproblemen. Inmiddels is deze basisverzekerde voetzorg van toepassing voor alle mensen met risicoprofiel Sims 2 en 3, ongeacht wie de hoofdbehandelaar van de diabetes is (huisarts, medisch specialist of specialist ouderengeneeskunde). Afhankelijk van welke medicus de hoofdbehandelaar is, verloopt de bekostiging van de (diabetes)podotherapeut en medisch pedicure via de zorggroep, zorgverzekeraar of een woon-zorginstelling. In veel gevallen is deze vergoeding ingericht volgens het principe van prestatiebekostiging, waarbij afhankelijk van de vastgestelde Sims classificatie en het bijbehorende zorgprofiel, een vast kwartaalbedrag aan de (diabetes)podotherapeut of zorggroep wordt uitgekeerd. Voor dit bedrag moet alle preventieve zorg geleverd worden die nodig is om complicaties te voorkomen. De (diabetes)podotherapeut of huisarts heeft daarbij de rol als hoofdaannemer en schakelt vanuit het principe van taakdelegatie de medisch pedicure in. De medisch pedicure werkt daarbij volgens het door de (diabetes)podotherapeut of huisarts opgestelde behandelplan. 
Een essentiële voorwaarde om de zorg op deze manier te organiseren is de Zorgmodule Preventie Diabetische Voetulcera, waarvan in 2019 de derde versie is uitgekomen (NVvP en ProVoet, 2019). Deze zorgmodule sluit volledig aan op de Richtlijn Diabetische Voet 2017 (NIV, 2017) en beschrijft de taken en verantwoordelijkheden van zowel de (diabetes)podotherapeut als de medisch pedicure. De zorg wordt geleverd volgens de vijf hoekstenen van preventie (zie kader), waarbij wordt uitgegaan van persoonsgerichte zorg aan de hand van de individuele zorgbehoefte van de persoon met diabetes. In de praktijk betekent dit bijvoorbeeld dat de ene persoon met Sims 3 voldoende heeft aan 10 instrumentele behandelingen op jaarbasis om nieuwe complicaties zoals (pre-)ulcera te voorkomen, terwijl bij een andere persoon met Sims 3 minder of meer behandelingen benodigd zijn om ditzelfde resultaat te bereiken. De vijf hoekstenen in de preventie van een voetulcus zijn:

1. Jaarlijks voetonderzoek (screening) en herkenning van de voet met een verhoogd risico

2. Gericht (voet)onderzoek bij mensen met een verhoogd risico

3. Schoeisel en andere hulpmiddelen

4. Follow-up en educatie

5. Regelmatige voetzorg

Hoewel preventieve diabetische voetzorg normaal gesproken vooral bestaat uit het leveren van fysieke zorg, was dit de afgelopen maanden niet altijd mogelijk door de uitbraak van COVID-19. Om deze essentiële zorg toch doorgang te laten vinden is er ook gebruik gemaakt van digitale en telefonische zorg. Hierbij is, zoals beschreven in de praktische handreiking voor (diabetes)podotherapeuten (NVvP, 2020) en de door de Nederlandse Diabetes Federatie (NDF) opgestelde multidisciplinaire afspraken (NDF, 2020), een duidelijk onderscheid aangebracht tussen de noodzakelijke fysieke (spoed)zorg, bijvoorbeeld bij mensen met ingegroeide teennagels en (pre-)ulcera, en zorg die tijdelijk digitaal of telefonisch geleverd kon worden.

Als sluitstuk voor alle ontwikkelingen in het afgelopen decennium is er inmiddels onder leiding van de NDF een traject opgestart om tot multidisciplinaire afspraken onder alle diabetische voetzorgverleners te komen. Juist doordat diabetische voet- en wondzorg bij uitstek multidisciplinaire zorg is, geloven wij sterk in de kracht van verbinding. Alleen dan kunnen we op effectieve wijze vroegdiagnostiek inzetten en ook 'delay' voorkomen als er toch complicaties zijn ontstaan. We hopen dan ook dat deze afspraken gebruikt gaan worden om multidisciplinaire regionale samenwerkingsafspraken tussen de eerste en tweede lijn te maken. De komende jaren zullen daarnaast in het teken van dataverzameling staan. Hierbij denken we aan data ten aanzien van het aantal (pre-)ulcera en amputaties, maar ook over de kosteneffectiviteit van de preventieve diabetische voetzorg.

Zorg is nooit af en kan altijd beter! Dit geldt zeker ook voor de diabetische voet- en wondzorg in Nederland. Met dit artikel hebben we getracht vanuit een beleidsmatig perspectief te laten zien welke randvoorwaarden inmiddels aanwezig zijn. We hopen dat de gezette stappen het komende decennium zullen bijdragen om het aantal ulcera en amputaties, en het hieruit voortkomende leed, te verminderen en de kwaliteit van leven van mensen met diabetes te verbeteren.

\section{LITERATUUR}

College Voor Zorgverzekeringen. Voetzorg voor mensen met diabetes mellitus. Rapport jan. 2010 - publicatie nummer 284. Nederlandse Diabetes Federatie. (2020). Multidisciplinaire leidraad: voetzorg ten tijde van COVID-19. https://diabetesfederatie.nl/nieuwsberichten/779-multidisciplinaire-leidraadvoetzorg-ten-tijde-van-covid-19.

Nederlandse Internisten Vereniging. (2017). Richtlijn Diabetische voet. https://richtlijnendatabase.nl/richtlijn/ diabetische_voet/startpagina_diabetische_voet.

html\#algemeennhg.

Nederlandse Vereniging van Podotherapeuten. (2020).

Diabetische voet- en wondzorg gedurende de uitbraak van COVID-19. https://www.podotherapie.nl/files/professional/ informatiemateriaal/diabetischevoet-enwondzorgtijdenscovid-19.pdf

Nederlandse Vereniging van Podotherapeuten, ProVoet. (2019). Zorgmodule Preventie Diabetische Voetulcera. https://www. podotherapie.nl/files/professional/informatiemateriaal/ zorgmodule-preventie-diabetische-voetulcera-2019.pdf

\section{TYPE 2 DIABETES MELLITUS BIJ KINDEREN}

Prof. Edgar G.A.H. van Mil, MD, PhD, Kinderartsendocrinoloog, Jeroen Bosch ziekenhuis 's-Hertogenbosch \& Bijzonder hoogleraar Jeugd, Voeding en Gezondheid, Maastricht University, Brightland Campus Greenport Venlo

Diabetes mellitus type 2 (DM2) wordt in de volksmond nog altijd 'ouderdomssuiker' genoemd. In de laatste decennia neemt de prevalentie in de westerse wereld toe, waarbij de laatste jaren ook de jeugd risico loopt. Bij jeugdigen met een ernstige mate van overgewicht wordt prediabetes, zoals een gestoorde glucosetolerantie, vaak per toeval ontdekt. Zoals bij volwassenen ontstaat ook bij kinderen en tieners DM2 wanneer de insulineaanmaak niet aan de toenemende vraag kan voldoen als gevolg van insulineresistentie, waarbij uiteindelijk ook B-celdisfunctie een rol speelt. Wetenschappelijk onderzoek levert aanwijzingen dat de achteruitgang in B-celfunctie bij adolescenten sneller gaat dan bij volwassenen. Tevens lijkt de morbiditeit en mortaliteit van de geassocieerde metabole complicaties, zoals dislipidemie, hoge bloeddruk en leververvetting, hoger bij volwassenen bij wie DM2 al op jeugdige leeftijd is ontstaan.

Ondanks dat de criteria niet apart voor jeugdigen zijn gevalideerd, is de diagnose van DM2 overeenkomstig met die van volwassenen. Echter, die relatief recente opkomst van deze verstoringen van de glucosehuishouding bij jongeren maken dat de diagnose, aanpak en monitoring de behandeling nog veel vragen oproepen.

Nog duidelijker dan bij volwassenen kenmerkt de pathofysiologie van DM2 in de jeugd zich door insulineresistentie, welke vaak al op de kinderleeftijd zichtbaar is. Als gevolg van de snelle spiegelstijging van geslachtshormonen neemt in de puberteit de insulinegevoeligheid verder 
af, waardoor juist in deze leeftijdsfase het ontstaan van DM2 sterk verhoogd is. Andere risico verhogende factoren zijn een bepaalde genetische achtergrond, een positieve familie-anamnese maar bijvoorbeeld ook polycysteus ovariumsyndroom of status na geboorte gecompliceerd door diabetes gravidarum of intra-uteriene groeiretardatie. Het geheel aan factoren bepaalt de kans op het daadwerkelijk ontstaan van DM2.

$\mathrm{Na}$ het bekend worden van prediabetes is het primaire doel vanzelfsprekend het voorkomen van DM2. Preventie richt zich op verbetering van de leefstijl door verlaging van calorische inname en verhoging van lichamelijke activiteit. Indien succesvol, is dit voldoende effectief om DM2 uit te stellen, mogelijk te voorkomen, zelfs in de pubertaire fase. In de praktijk blijkt leefstijlverbetering in de tienerleeftijd helaas een lastig te behalen doel. Hierom is in een Nederlandse studie het additioneel effect van metformine bij insulineresistente tieners onderzocht die reeds deelnamen aan een leefstijlinterventiestudie. $\mathrm{Na}$ een initieel gunstig effect van metformine op overgewicht en HbA1c kon deze winst in het verloop van de studie onvoldoende behouden blijven. In de huidige Nederlandse richtlijn voor de behandeling van overgewicht met insulineresistentie wordt dan ook geadviseerd terughoudend te zijn met medicamenteuze ondersteuning, of hooguit kortdurend voor te schrijven. Is DM2 eenmaal ontstaan, dan is de behandeling volgens de internationale ISPAD-voorschriften opnieuw metformine eventueel met insulinetherapie hieraan toegevoegd, afhankelijk van de mate van ontregeling bij diagnose. Echter indien een patiënt met een initieel metabool stabiele diagnose met $\mathrm{HbAlc}<69$, binnen 4 maanden met behulp van metformine monotherapie niet daalt naar een $\mathrm{HbAlc}$ $<53 \mathrm{mmol} / \mathrm{mol}$, dan wordt ook gestart met langwerkende insuline en uiteindelijk ook maaltijdinsuline.

Sulfonylureumderivaten zijn in de meeste landen onder de 18 jaar niet geïndiceerd. Belangrijkste reden hiervoor is de kans op hypoglykemiën. In een klinisch onderzoek kon de meerwaarde boven metformine niet worden aangetoond en waren er aanwijzingen voor gewichtstoename en versnelling van het verlies aan B-cel functie.

De incretinehormonen verhogen de insulineafgifte op een glucose bolus, remmen glucagonafgifte en vertragen maagontlediging en verhogen verzadiging. De DPP4-remmers geven een soortgelijk effect omdat deze middelen de afbraak van incretines remmen. Vertraging van de maagontlediging met verhoging van verzadiging en gewichtsverlies komt hierbij echter niet voor. In de Ellipse studie werd het incretinehormoon liraglutidine toegevoegd aan de behandeling met metformine al dan niet in combinatie met insulinetherapie bij adolescenten met DM2. Vergeleken met een placebo nam de HbAlc significant meer af in een half jaar tijd maar dit ging eveneens gepaard met een toename van gastro-intestinale klachten. Ook de DPP4-remmer sitagliptine werd onderzocht in deze leeftijdsgroep echter hierbij werd niet naar effectiviteit maar naar de farmacologische werking en veiligheid gekeken. In Nederland zijn op dit moment enkel metformine en liraglutine voor kinderen $>10$ jaar geregistreerd indien diabetes met dieet en lichaamsbeweging onvoldoende gereguleerd kan worden.
Voor veel van de overige bloedsuiker verlagende middelen die reeds geregistreerd staan voor volwassenen worden nu studies voorbereid voor (pre-)adolescenten. Voor sommigen middelen zoals canagliflozine of dapagliflozine, SGLT-2-remmers, is wel reeds naar de farmacologische werking en veiligheidspofiel gekeken in deze kwetsbare doelgroep.

Gezien de bij adolescenten mogelijk extra ongunstig prognose van complicaties zoals de hoge bloeddruk, microalbuminurie, dislipidemie, leververvetting, dient hier actief op gescreend te worden. Naast het opstarten van gerichte farmacotherapeutische behandeling horen hierbij eveneens de bedreigingen van gezonde leefstijl zoals slaapdeprivatie, alcohol en roken meegenomen te worden.

De basis van de behandeling blijft leefstijlverbetering zoals dit ook voor de preventieve maatregelen tegen DM2 het geval is. Echter in geval van DM2 dient hier nog meer nadruk op gelegd te worden door met patiënt en ouder(s) te kijken welke kansen en belemmeringen hierbij spelen en hoe hiermee om te gaan. Dit vergt het aanwenden van specifieke competenties zowel bij ouders/verzorgers van de patiënt als bij de betrokken professionals. Een integrale aanpak waarbij de zorg en gemeente/welzijnsinstanties waar nodig ondersteuning bieden, gecoördineerd door een centrale zorgverlener, in de praktijk veelal de gespecialiseerd diabetesverpleegkundige, kan hierin veel effect bereiken. Idealiter kan zo nog nuttig gebruik worden gemaakt van de structuur die vaak vanuit het ouderlijk huis nog wordt geboden, maar daarna in de begin fase van zelfstandig wonen meer op de achtergrond komt te staan.

\section{SUBTYPERING DIABETES TYPE 2 EN \\ GEPERSONALISEERDE LEEFSTIJLINTERVENTIE}

Anne-Margreeth Krijger, apotheker bij Academische Apotheek Stevenshof Leiden en SIR institute for Pharmacy

Practice and Policy Leiden

Susanne Berbée, diëtist, gezondheidscentrum Stevenshof Leiden (diëtiste)

Suzan Wopereis, senior onderzoeker, afdeling Microbiologie en Systeembiologie, TNO, Zeist

In 2019 heeft de pilot 'diabetypering en leefstijl als medicijn' in de eerstelijns zorgpraktijk in Leiden, in samenwerking met TNO, plaatsgevonden. Diabetypering houdt in dat via een uitgebreide 5-punts orale glucosetolerantietest (OGTT) bepaald wordt of iemand insulineresistentie heeft van de lever en/of de spieren en hoe de alvleesklier van iemand functioneert. Hiervoor wordt op 5 tijdstippen zowel glucose als insuline gemeten; in nuchter bloed en vervolgens elke 30 minuten na inname van een 75 gram glucosebolus. Algoritmes vertalen deze glucose en insuline concentraties in de mate van insulineresistentie van lever, spier en de capaciteit van de bètacel van de alvleesklier. Op basis van het combineren van deze uitslagen kunnen een totaal van 8 verschillende subtypes van diabetes mellitus type 2 (DM2) onderscheiden worden, op basis waarvan de focus van de leefstijlinterventie wordt bepaald. Of en hoe iemand zijn DM2 kan omkeren, hangt ook af van de sociaaleconomische omgeving, leefstijlgedrag, denken en gevoel van de 
patiënt. Iedere deelnemer vulde daarom online vragenlijsten in om deze persoonlijke facetten van de zogenaamde 360 graden diagnose in kaart te brengen. Daarnaast waren er intakegesprekken met de diëtiste en de apotheker om een compleet beeld te krijgen van de eet- en drinkgewoonten en het medicatiegebruik en (mogelijke) bijwerkingen. Zowel het DM2-subtype als de persoonlijke en contextuele informatie werd voor iedere deelnemer samengebracht in een persoonlijk profielwiel, ontworpen door TNO, om de uitslag van de 360 graden diagnose met stoplichtkleuren te visualiseren (zie figuur 1). Dit wiel vormde de basis voor het multidisciplinaire overleg en werd vervolgens gebruikt bij het gesprek tussen de deelnemer en de praktijkondersteuner en diëtiste, waarbij gezamenlijk de doelstellingen voor de gepersonaliseerde leefstijlinterventies op gebied van voeding, beweging en medicatieafbouw werden vastgesteld.

Totaal zijn 15 DM2-patiënten geïncludeerd in de pilot met variabele ziektestatus en ziekteduur, waarvan 14 personen orale bloedsuikerverlagende medicatie, GLP-1-injecties en/of insuline gebruikten en één persoon niets. De deelnemers kregen een half jaar individuele begeleiding door de praktijkondersteuner en de diëtiste, alsmede groepsconsulten met alle eerstelijns zorgverleners (apotheker, diëtiste, huisarts, praktijkondersteuner). Na 3 en 6 maanden werd nogmaals het DM2-subtype bepaald middels de uitgebreide OGTT-test en werden de vragenlijsten opnieuw ingevuld voor de 360 graden diagnose. Op basis hiervan kon het effect van de persoonlijke leefstijlinterventies beoordeeld worden en richting worden gegeven aan de vervolgstappen. Na 3 maanden waren er voor alle deelnemers verbeteringen op het gebied van de bloedglucoseregulatie (HbAlc), insulineresistentie (lever en/of spier), functioneren van de alvleesklier en afname van bloedsuikerverlagende medicatie. Echter de ingezette leefstijlverandering ging tussen 3 en 6 maanden ook gepaard met perioden van terugval. $\mathrm{Na} 6$ maanden had 40\% de diabetes in remissie gebracht (geen bloedsuikerverlagende medicatie meer en normale HbA1c waarden) of diabetes omgekeerd (reductie van bloedsuikerverlagende medicatie en verbeterde $\mathrm{HbA1c}$ waarden). De uitslag van de laatste OGTT-test motiveerde de 'terugvallers' om de beoogde gedragsverandering te hervatten.

Samenvattend, het subtyperen van DM2 gaf - voor zowel patiënten en zorgverleners - inzicht in de onderliggende pathofysiologie en richting aan de leefstijl- en medicamenteuze behandeling. Het profielwiel gaf daarbij verder inzicht in belangrijke aspecten die mee zijn genomen in het verfijnen van de persoonlijke leefstijlinterventie, zoals slapen, beweging, stress (reductie) en invloed omgeving. Het combineren van de kennis en verdelen en afstemmen van de zorg hadden een positief effect op de multidisciplinaire samenwerking in de eerste lijn. Langdurige begeleiding en coaching lijken een randvoorwaarde voor een succesvolle leefstijl behandeling.

In conclusie, het is aan te bevelen diabetypering onderdeel te maken van de reguliere behandeling van DM2, zodat er op meer parameters genavigeerd kan worden dan alleen op glucose en/of HbAlc-uitslagen. Tevens heeft het vormen van multidisciplinaire expertteams op het gebied van leefstijlinterventies en langdurig begeleiden van DM2-patiënten in groepsverband een meerwaarde ten opzichte van de huidige reguliere behandeling. Hoe dat praktisch vorm gegeven kan worden in de dagelijkse eerstelijns diabeteszorg willen we graag met $u$ onderzoeken en bediscussiëren tijdens de NDD.

\section{GECOMBINEERDE LEEFSTIJLINTERVENTIES OP MAAT}

Marjolein van Driel, leefstijlcoach en fysiotherapeut, LifeLein leefstijlcoaching te Bussum en Amsterdam, Slow Sports trainer met 'Keurmerk Oog voor Diabetes', Elise (E.R.G.) Kuipers, leefstijlcoach en diëtist, Dietistenpraktijk Elise Kuipers te Amsterdam, bestuurslid Stichting DNO Diabetesdiëtist, Lid werkgroep herziening NDF Voedingsrichtlijn 2015

Sinds januari 2019 wordt de Gecombineerde Leefstijl Interventie (GLI) via de basisverzekering aangeboden zonder verrekening met eigen risico. Doelgroep van de GLI

Figu ur 1. het profielwiel ('360 graden diagnose').

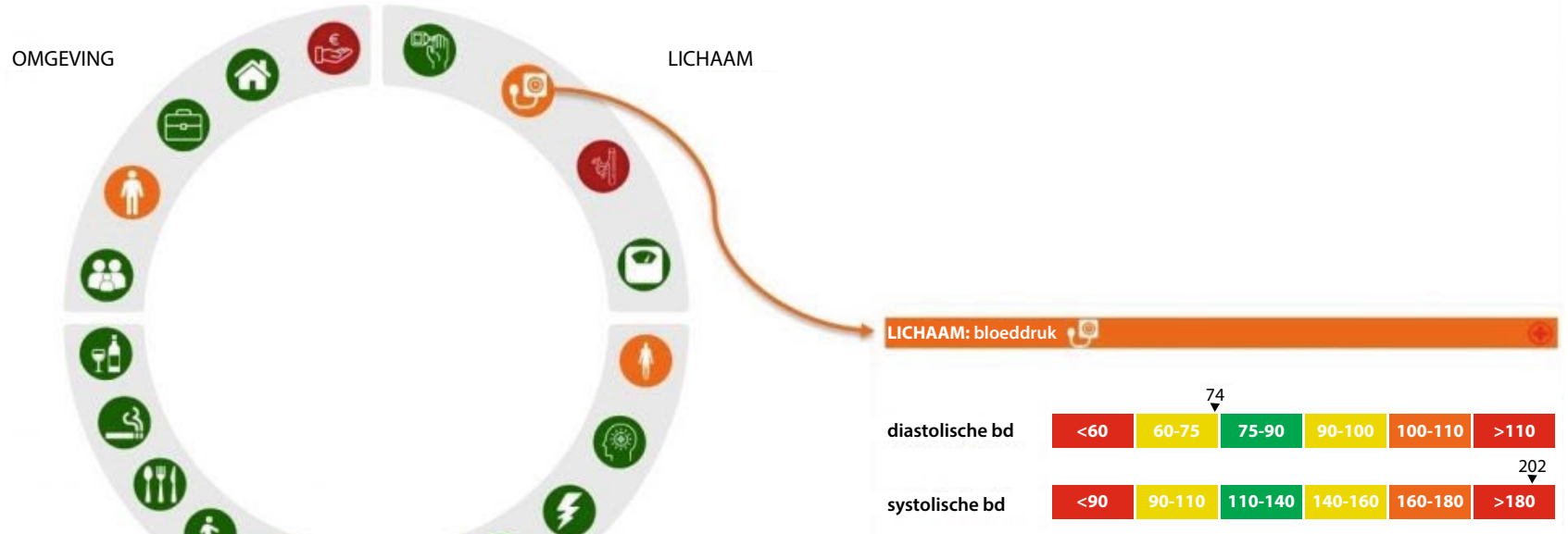

GEDRAG 
zijn personen met overgewicht (BMI 25-30) met risicofactoren zoals diabetes type 2 , hart- en vaatziekten, slaapapneu of artrose als ook personen met obesitas (BMI 30 en hoger) al dan niet met genoemde risicofactoren. Het doel is $5 \%$ gewichtsvermindering in 2 jaar, maar vooral verbetering van gezondheid en kwaliteit van leven. Via deelname aan de GLI worden personen gecoacht in gedragsverbetering en behoud op het gebied van leefstijl zoals voeding, beweging, stress, ontspanning en slapen.

In Nederland worden 3 GLI's via de basisverzekering vergoed, te weten Beweegkuur, Slimmer en CooL. Alle GLI's bestaan uit individuele consulten en groepsbijeenkomsten. Het grootste verschil is dat Beweegkuur en Slimmer door een fysiotherapeut en diëtist, die beiden tevens leefstijlcoach zijn, wordt uitgevoerd; CooL wordt alleen door een leefstijlcoach gedaan. Het grootste misverstand in het land is dat de GLI's een beweegprogramma aanbieden. De GLI zet aan tot en motiveert de deelnemer om zelf in zijn eigen omgeving in beweging te komen.

De grootste zorgverzekeraar in Amsterdam stelt als voorwaarde dat de GLI aangeboden wordt via de zorggroep. Amsterdam en omgeving bestaat uit 9 zorggroepen die zich verenigd hebben in de Amsterdamse Huisartsen alliantie. Deze alliantie heeft zorggroep ROHA het recht gegeven om het GLI contract met de zorgverzekeraar te tekenen, als ook de contracten met de GLI aanbieders vast te leggen en uit te betalen.

Zorggroep ROHA bewaakt in samenwerking met de Eerstelijn Amsterdam (ELAA) de kwaliteit van de GLI:

- Alleen GLI-aanbieders die samenwerken met de wijk komen in aanmerking voor een contract

- GLI-aanbieders komen 2-3x per jaar samen voor meer transparantie over het aanbod, samenwerking, verdeling over de wijken etc.

- GLI-aanbieders delen ervaringen en kunnen niet uitgespeeld worden door deelnemers die shoppen bij de verschillende Amsterdamse GLI-aanbieders

- Via ROHA en ELAA worden huisartsen geïnformeerd over de gang van zaken rondom de GLI

Specifiek bij personen met diabetes, afhankelijk van de soort medicatie, is er risico op hypoglykemie bij verbeteringen in het eet- en beweegpatroon. Daartoe is overleg en verwijzing door de leefstijlcoach naar het diabetesteam in het ziekenhuis of zorggroep vereist. Het doel van behandeling van de (diabetes)diëtist is dan niet afvallen, maar afstemming voeding (koolhydraten) en medicatie. En zo nodig kan in overleg met de arts/dvk afbouw van medicatie plaatsvinden.

\section{DIABETES ON RETURN; DE MOGELIJKHEDEN VAN TECHNOLOGIE IN DEZE}

Miriam Vollenbroek-Hutten, Goos Laverman internist-nefroloog, Ziekenhuis Groep Twente en Universiteit Twente

In Nederland zijn meer dan een miljoen mensen met diabetes. Voor velen van hen is diabetes een dagelijkse worsteling, bijvoorbeeld om de bloedsuikers op orde te houden, vitaal te blijven of medicatie niet te vergeten. Ondanks dat behandelingen steeds beter zijn geworden in de afgelopen decennia, heeft de ziekte heeft nog steeds een enorme impact, niet alleen in het dagelijkse leven, maar denk ook aan de langetermijncomplicaties.

Diabetes on Return is een groot landelijk samenwerkingsverband tussen onderzoekers, patiëntvertegenwoordigers, zorgprofessionals en bedrijven en wordt geleid vanuit de Universiteit Twente. Diabetes on Return is opgezet om innovatieve technologieën te ontwikkelen, te onderzoeken en beschikbaar te maken om personen met diabetes te helpen in hun strijd met diabetes.

Technologieën zijn gericht op gebruik in het dagelijkse leven zonder dat ze veel inspanning van de patiënt vragen. Het gaat voor een deel om het verzamelen van informatie, zoals het meten van parameters voor inzicht in de gezondheid van de patiënt, zoals glucosespiegels, conditie van vaten en informatie over voeding en beweging. We werken aan systemen en behandelingen die laagdrempelig en beter de juiste hoeveelheid toe te dienen insuline inschatten, aan systemen die effectief zijn voor leefstijlverbetering, maar ook aan technologieën die de huidige insulinetoediening via pompen verder verbeteren.

Een mooi voorbeeld is de Diameter-app, waarin een aantal belangrijke functies zijn geïntegreerd, en die zodanig is ontwikkeld dat steeds nieuwe functies kunnen worden toegevoegd. De Diameter geeft de diabetespatiënt inzicht in de continue glucosewaardes, de tijd 'binnen doelbereik' en hoe deze over de tijd varieert. Ook wordt door de Diameter beweging en voeding gemonitord. De lichamelijke activiteit wordt automatisch geregistreerd met een Fitbit-sensor en voeding via een slimme voedingsregistratie. De aldus verzamelde informatie geeft niet alleen algemeen inzicht maar integratie van de gegevens geeft inzicht in de effecten van leefstijl op de glucosespiegel, een potentieel krachtige manier voor de patiënt om zelf de glucosewaardes gunstig te beïnvloeden zonder medicatie-aanpassingen. De Diameter kan ingezet worden om, gebaseerd op de metingen, samen met de zorgprofessional persoonlijke doelen te stellen. Vervolgens helpt de Diameter om deze doelen te realiseren, ten eerste door de metingen, maar ook door een ingebouwde digitale buddy die in het dagelijkse leven begeleidt/aanmoedigt om de doelen te realiseren. Recente kortetermijnstudies in 30 patiënten leren dat deze aanpak door patiënten wordt ervaren als 'zeer waardevol'.

Ontwikkelingen als bovenstaande vinden plaats in wat we 'proeftuinen' noemen. Dit betekent dat de patiënten betrokken zijn vanaf het eerste idee voor een innovatieve oplossing, bij de ontwikkeling doordat de technologieën gedurende de ontwikkeling voortdurend worden getest en de resultaten hiervan worden gebruikt om de innovaties verder te verbeteren zodat ze goed aansluiten bij de behoeften en wensen van de patiënt. In deze proeftuinen vindt ook nauwe samenwerking plaats tussen de belangrijke regionale partijen zoals zorgaanbieders en verzekeraars. Dit is cruciaal om te borgen dat technologieën die bewezen werkzaam zijn ook daadwerkelijk worden geïmplementeerd in de dagelijkse praktijk. 
Zie bijvoorbeeld Melmer, A, Züger, T, Lewis, DM, Leibrand, S, Stettler, C, Laimer, M. Glycaemic control in individuals with type 1 diabetes using an open source artificial pancreas system (OpenAPS). Diabetes Obes Metab. 2019; 21: 23332337.

\section{DIABETES TYPE 1 EN GEASSOCIEERDE AUTO-IMMUUNAANDOENINGEN BIJ KINDEREN EN VOLWASSENEN}

\section{R. Mentink, Diaboss, Amsterdam}

\section{C.B. Brouwer, OLVG, Amsterdam}

Een kind of volwassene met diabetes mellitus type 1 heeft meer kans om een andere auto-immuunaandoening te ontwikkelen. In een recente Finse studie, waarin werd gekeken naar de prevalentie van schildklieraandoeningen, coeliakie, primaire bijnierschorsinsufficiëntie en atrofische gastritis bij volwassenen met diabetes type 1, bleek dat $20 \%$ van de patiënten een andere auto-immuunaandoening had. ${ }^{1}$ De prevalentie bij kinderen met diabetes type 1 verschilt per onderzoek; de meest voorkómende aandoeningen (coeliakie en hypo- of hyperthyreoïdie) komen tot $10 \%$ voor. ${ }^{2}$ Vanwege deze hoge prevalenties en omdat de symptomatologie niet altijd evident is, is screening op andere auto-immuunaandoeningen in alle leeftijdsgroepen noodzakelijk.

Binnen de kindergeneeskunde is er is een richtlijn van de International Society for Pediatric and Adolescent Diabetes (ISPAD) waarin adviezen worden gegeven over hoe vaak en waarop gescreend zou moeten worden. Uit recent onderzoek onder de Nederlandse kinderdiabetescentra blijkt dat er met deze screening heel verschillend wordt omgegaan. ${ }^{3}$ Van de onderzochte centra was er niet één die volledig de ISPAD-richtlijnen opvolgde: alle centra deden vaker en vooral ook meer onderzoek. Dit leidt tot hogere zorgkosten maar ook tot meer belasting voor de patiënt, met name in deze jonge patiëntengroep.

In de richtlijnen binnen de interne geneeskunde, zoals die van Zorgstandaard Diabetes ${ }^{4}$, de Nederlandse Internisten Vereniging (NIV) ${ }^{5}$ en van de American Diabetes Association
$(\mathrm{ADA})^{6}$ wordt wel benoemd dát er gescreend moet worden op auto-immuunaandoeningen, maar niet met welke frequentie. Er wordt door de ziekenhuizen of diabetescentra dan ook erg verschillend met de screening omgegaan.

Gezien de hoge prevalentie van geassocieerde auto-immuunaandoeningen bij patiënten met diabetes type 1 is screening hierop essentieel. Overdiagnostiek is echter ook niet nodig. Richtlijnen voor screening zijn waar mogelijk wetenschappelijk onderbouwd en kunnen de zorgverlener adviseren op het gebied van screening. Daarbij is het altijd van belang om het advies te individualiseren op basis van de patiënt die tegenover de zorgverlener zit: er zijn goede redenen om van richtlijnen af te wijken. Aan de hand van casuïstiek zal besproken worden hoe de presentatie van andere auto-immuunaandoeningen kan zijn en zal geprobeerd worden een onderbouwd screeningsadvies te formuleren. Op deze manier worden geassocieerde auto-immuunaandoeningen niet gemist, zorgkosten beperkt en de patiënt minder belast.

\section{REFERENTIES}

1 Mäkimattila $S$ et al. Every fifth individual with type 1 diabetes suffers from an additional autoimmune disease: a Finnish nationwide study. Diabetes Care 2020 May; 43(5): 1041-1047.

2 Mahmud FH et al. ISPAD Clinical Practice Consensus Guidelines 2018: Other complications and associated conditions in children and adolescents with type 1 diabetes. Pediatr Diabetes. 2018 Oct; 19 Suppl 27:275-286.

3 Mentink R, Straaten E van, Schagen SEE. Screening for complications and associated conditions in children and young adults with type 1 diabetes mellitus. Nog niet gepubliceerd.

4 https://www.zorgstandaarddiabetes.nl/type-1/

5 https://www.internisten.nl/werken-als-internist/ richtlijnenindicatoren/overzicht-richtlijnenindicatoren

6 American Diabetes Association. Comprehensive medical evaluation and assessment of comorbidities: standards of medical care in Diabetes - 2020. Diabetes Care 2020;43(Suppl. 1):S37-S47.

\begin{tabular}{l|l}
\hline Sessie & Spreker \\
\hline 1. De diabetessamenleving & Maria van den Muijsenbergh \\
\hline 2. De nieuwe NHG-Standaard CVRM: hoe pak je dat aan in de dagelijkse praktijk? & Voorzitters: Diana Rietdijk \& Janneke Spitsbaard-Velmans \\
\hline 3. Closing the loop & Sprekers: Marc Huls, Jaap Kroon, Bertien Hart, Wilko Spiering \& Jan Westerink \\
\hline 4. Vaste voet aan de grond & Organisator: Roel Nahuis, voorzitter: Hans de Vries \\
\hline 5. DM type 2 bij kinderen: welke middelen wel en niet? & Sprekers: Joost Hart, Bas Schouwenberg, Annette van Raamsdonk, Henk Jan Aanstoot \\
\hline 6. Subtypering diabetes type 2 en gepersonaliseerde leefstijilinterventie & Michel Boerrigter \& lgna Breedeveld \\
\hline 7. Gecombineerde leefstijilinterventies op maat & Edgar van Mil \\
\hline 8. Diabetes on return en de mogelijkheden van technologie hierbij & Anne-Margreeth Krijger, Suzan Wopereis \& Susanne Berbée \\
\hline 9. Diabetes type 1 \& geassocieerde auto-immuunaandoeningen bij kinderen en volwassenen & Elise Kuipers en Marjolein van Driel \\
\hline & Goos Laverman \& Miram Vollenbroek-Hutten \\
\hline
\end{tabular}

